\section{Binge drinking, alcohol outlet density and associated factors: a multilevel analysis among adolescents in Belo Horizonte, Minas Gerais State, Brazil}

\author{
Consumo excessivo episódico de álcool, \\ densidade de locais de venda de bebidas \\ alcoólicas e fatores associados: uma análise \\ multinível entre adolescentes em Belo \\ Horizonte, Minas Gerais, Brasil
}

Consumo de alcohol compulsivo, densidad de locales de venta de alcohol y factores asociados: un análisis multinivel entre adolescentes procedentes de Belo Horizonte, estado de Minas Gerais, Brasil

\begin{abstract}
Our study sought to evaluate the prevalence of binge drinking in adolescents and its association with density of alcohol outlets around schools. This crosssectional study was conducted in Belo Horizonte, Minas Gerais State, Brazil, with 436 high-school students aged between 17 and 19 and enrolled in 18 public and private schools. The students completed the Alcohol Use Disorder Identification Test (AUDIT-C), consisting of questions about alcohol consumption by parents and siblings, and socioeconomic status (type of school, mother's education level). Data from geographic information systems were used to estimate the density of alcohol outlets around schools participating. The association between exploratory variables and binge drinking was investigated using multilevel logistic regression analysis $(p<0.05)$ with random intercepts and fixed slopes. A three-step sequential modeling strategy was adopted. The prevalence of binge drinking was 39.9\%. The alcohol consumption among adolescents was lower for those studying in areas with low density of alcohol outlets around schools $(\mathrm{OR}=0.32$; 95\%CI: $0.14 ; 0.73)$ and the consumption of alcohol by mothers was associated with binge drinking among adolescents $(O R=1.94 ; 95 \% \mathrm{CI}: 1.14 ; 3.30)$. Our study concluded that binge drinking among adolescents was associated with density of alcohol outlets around the schools and mother's alcohol consumption.
\end{abstract}

Alcohol Consumption; Binge Drinking; Adolescent
Juliana Gabrielle Martins 1

Mariana Oliveira Guimarães 2

Kelly Oliva Jorge 3

Carlos José de Paula Silva 2

Raquel Conceição Ferreira 2

Isabela Almeida Pordeus 2

Ichiro Kawachi 1

Patrícia Maria Pereira de Araújo Zarzar 2

doi: 10.1590/0102-311X00052119

\author{
Correspondence \\ P. M. P. A. Zarzar \\ Rua Gustavo Ladeira 11, bloco 4, apto. 1104, Belo Horizonte, \\ MG 31330-572, Brasil. \\ patyzarzar@hotmail.com \\ 1 Harvard School of Public Health, Boston, U.S.A. \\ 2 Universidade Federal de Minas Gerais, Belo Horizonte, Brasil. \\ 3 Universidade Vale do Rio Verde, Belo Horizonte, Brasil.
}




\section{Introduction}

Adolescent binge drinking represents a public health concern capable of damaging the individual and the collective ${ }^{1}$. Although alcohol sale and supply to people under 18 years old is prohibited by law in Brazil 2, alcohol is the most commonly used drug among the young population ${ }^{1}$. The last national drug survey revealed that $43.6 \%$ of Brazilian adolescents between 13 to 15 years old and $65.3 \%$ between 16 to 18 reported having consumed alcoholic beverages in the last year 3 . Violence, poor school performance, unprotected sex and drug use are multiple risk behaviors associated with this practice $4,5,6,7$.

The consumption of alcohol reflects the complex interactions of individual-level risk and protective factors with family expectation and community environment $8,9,10$. The same individual-level factors may produce differential effects when studied in distinct social contexts 11 . School characteristics, for example, constitute important contexts in which adolescents can develop deviant behaviors such as binge drinking 12 .

The physical availability of alcohol is characterized by alcohol outlet density (number of bars and liquor stores in a given location), which is a critical component in alcohol consumption behavior 13,14. Adolescents can purchase alcohol in outlets more easily, directly or indirectly, in some neighborhoods than in others 15. A study with Scottish adolescents concluded that individuals within 200 meters of an off-sales outlet were nearly twice more likely to drink weekly than those living more than 800 meters away from such establishments 16 .

Many scientific publications point to a positive association between proximity and density of local alcohol outlets and the higher consumption of alcoholic beverages among adolescents 14,16,17. However, most of these studies were conducted in Europe, Australia, North America and some Asian countries, with no studies on the topic in Latin American countries such as Brazil.

A study on the influence of alcohol outlet density in different contexts and cultures is recommended to the effectiveness of preventive measures against alcohol consumption, avoiding unnecessary public spending. Therefore, our study sought to investigate if adolescent binge drinking is associated with alcohol outlet density around school areas in Belo Horizonte, Minas Gerais State, Brazil.

\section{Methods}

\section{Study design and sampling}

A cross-sectional study was conducted with a convenience sample of 436 adolescents aged between 17 and 19 years and enrolled in second and third year of high school at public and private schools in the city of Belo Horizonte in 2012.

Belo Horizonte is the capital of Minas Gerais State. It has approximately 2,500,000 inhabitants. The city is geographically divided into nine administrative districts 18 .

Our study was part of a larger study conducted in 2010 with a representative sample of 936 adolescents between 15 and 19 years old. Of these students, 717 (81\%) were enrolled in public schools and 174 (19\%) in private schools. The proportion of adolescents between 15 and 19 years old enrolled in public and private schools was obtained from Belo Horizonte Education Secretariat and the distribution of students in each of the nine administrative districts were estimated. Two schools in each of the nine administrative districts ( 9 public and 9 private) and classrooms were randomly selected.

In 2012, a new data collection was conducted to evaluate high school students at 15 and 16 in 2010, the expected number of students was 529. The schools and the second and third-year students were contacted by phone and invited to participate. In classroom, the researchers explained the study objectives to the adolescents and asked them to answer the questionnaire, ensuring the confidentiality of answers and the participation evaluation. Our final sample was of 436 adolescents due to a $17.5 \%$ loss. Further details on the sample were found in a previously study 19,20. 


\section{Binge drinking}

Binge drinking, the dependent variable, was defined as the consumption of 5 or more drinks on one occasion. One drink contains $10-12 \mathrm{~g}$ of alcohol and corresponds to $350 \mathrm{~mL}$ of draft beer or $90 \mathrm{~mL}$ of wine, or $30 \mathrm{~mL}$ of a distilled beverage 21,22 . We used the Alcohol Use Disorder Identification Test (AUDIT-C), validated for Brazil to assess the alcohol consumption 22. The test consists of three questions, namely: "How often did you have a drink containing alcohol in the past year?" (answer options: "never", "monthly or less", "2 to 4 times a month", "2 to 3 times a week" and " 4 or more times a week"); "How many drinks containing alcohol did you have on a typical day when you were drinking?" (answer options: "1 or 2", "3-4", "5-6", "7-9" and "10 or more"); "How often do you have five or more drinks on one occasion?" (answer options: "never", "less than monthly", "monthly", "weekly", "daily or almost daily").

The binge drinking was obtained by the third question. The answer "never" was coded as 0 , "less than monthly", "monthly", "weekly" and "daily or almost daily" were coded as 1 in the analysis 23.

\section{Alcohol outlet density}

Data from geographic information system (GIS) were used to estimate the density of alcohol outlets around schools participating. Alcohol outlets were defined as on-site and off-site establishments licensed to sale alcohol. The information about the establishments were collected within a radius of $1 \mathrm{Km}$ from a central location point (CLP) in all 18 schools participating 24,25 .

The outlets licensed in the area of the study was estimated by a local master list of licenses provided by the City Counsel of Belo Horizonte and physical observation by the researchers. The offlicensed outlets were located manually using information from paper maps. These were counted and included in the analyses.

The local address CLP were executed using the software ArcView 9.3 (http://www.esri.com/ software/arcview/), and a radial limit of $1 \mathrm{Km}$ was established. After identifying the areas, $1 \mathrm{Km}$ (from one place to another) addresses of schools and alcohol outlets were geocoded using the automated geocoding function of ArcView, with which the software tries to match each address with the corresponding street on the database. All the addresses were found and mapped. The outlet density was stratified into "low", "mean" and "high" by GIS. Figure 1 mapped the data, illustrating how alcohol outlets are distributed around the selected schools. In the map, each triangle represents a school and each ball represents an alcohol outlet.

\section{Alcohol consumption by parents and siblings}

Alcohol consumption by parents and siblings were identified through the following questions: "Does your father drink alcoholic beverages?" (answer options: "0-no" or "1-yes"), "Does your mother drink alcoholic beverages?" (answer options: "0-no" or "1-yes"); "Do any of your brothers and sisters drink alcoholic beverages?" (answer options: "0-no" or "1-yes").

\section{Socioeconomic status}

The type of school (public or private) was used as an indicator of socioeconomic status. Although it is a crude assessment, wealthy adolescents in Brazil are usually enrolled in private schools because most of our public schools are known to have less educational resources than private ones 26,27.

Maternal education level has been associated with binge drinking among adolescents 27 . The mother's educational level corresponded to years of schooling; the cut-off point used was 7 years, the threshold was the average. The average years of schooling of the Brazilian population was 7.3 years, therefore, the cut-off point of 7 years is associated with the beginning of high school 28 . 
Figure 1

Density of alcohol outlets around schools. Belo Horizonte, Minas Gerais State, Brazil, 2012.

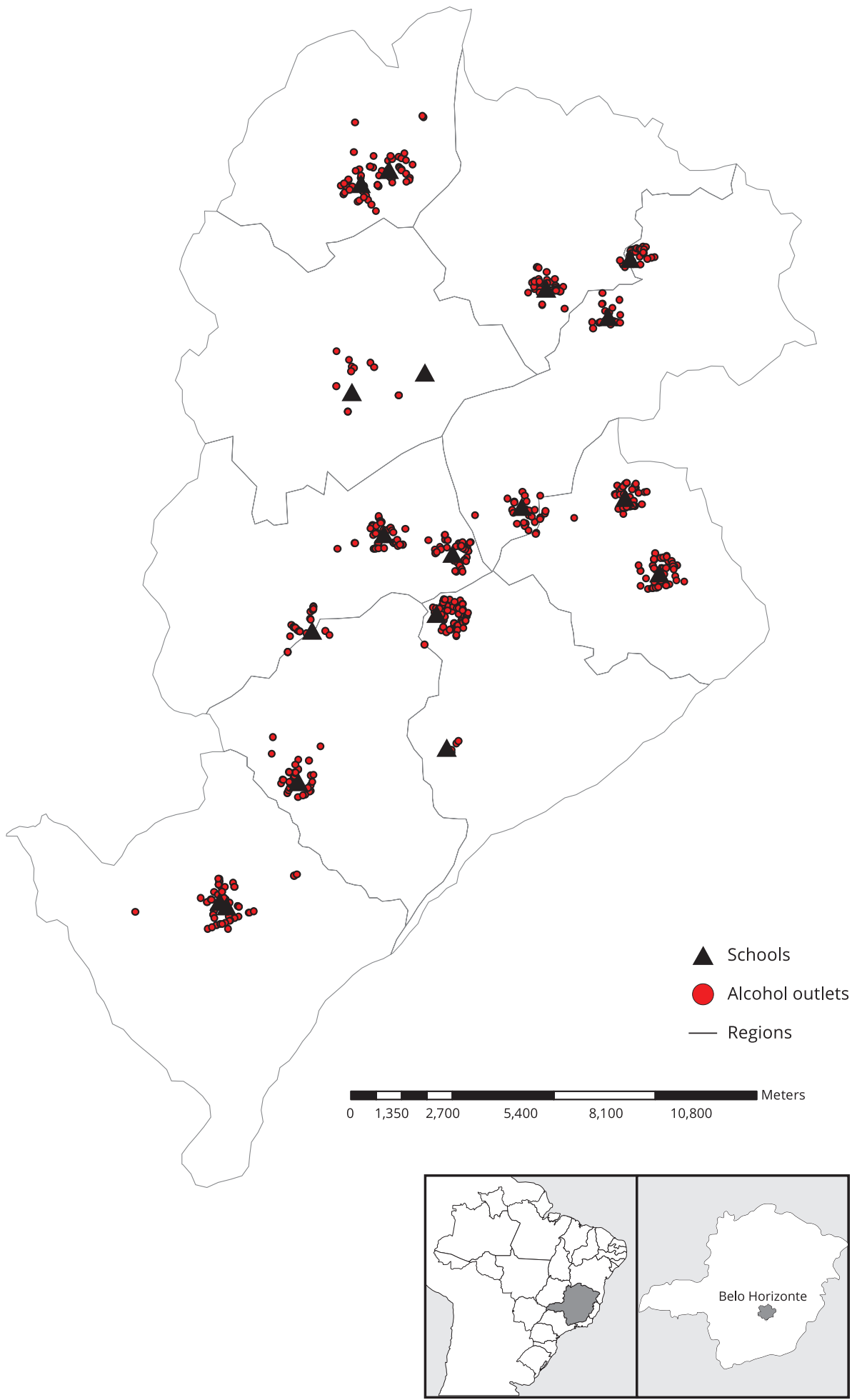




\section{Ethical considerations}

Our study was approved by de Human Research Ethics Committee of the Federal University of Minas Gerais (Brazil) (COEP: 124/08). Students' parents and guardians signed an informed consent form authorizing the participation of their children.

\section{Statistical analysis}

Data analysis was performed using the SPSS, version 22.0 (https://www.ibm.com/) and included frequency distribution and associated tests. The multilevel logistic regression was used to estimate the individual contextual predictors of binge drinking with $95 \%$ confidence intervals $(95 \% \mathrm{CI})$.

\section{Results}

The frequency of binge drinking was $39.9 \%(\mathrm{n}=174)$ in the sample of 436 adolescents between 17 and 19 years old. Regarding the age, $40.6 \%(n=177)$ were students with 17 years old and and $59.4 \%(n=$ 259) were between 18 or 19 years old. Regarding sex, 40.4\% $(n=176)$ were men. Table 1 shows more results of the distribution of sample according to the independent variables and bivariate analyses.

The association between exploratory variables and binge drinking was investigated using multilevel logistic regression analysis with random intercepts and fixed slopes. A three-step sequential modelling strategy was adopted: Model 1 (empty model): a model without predictors that the binge drinking is a function of schools. A significant random intercept variance indicates the existence of unexplained differences in binge drinking between schools. The significance of random intercept was evaluated using Wald test, and the median odds ratio (MOR) measured the heterogeneity among schools, according to Austin et al. 29. There is no variation between municipalities if the MOR was 1, but the higher the MOR, the greater the area-level variation. Model 2: considers all the contextuallevel variables in the fixed part. Model 3: same as model 2, including the individual-level variables. The proportional change in variance (PCV) was estimated according to Merlo et al. 30, using the following formula: $\mathrm{PCV}=$ (variance model $1-$ variance model 2$) /$ variance model 1 , as shown in Table 2.

The analysis of variance between schools (LR test chibar2 $=18.51, \mathrm{p}<0.0001$ ) and MOR (empty model) shows a heterogeneity significant in binge drinking between schools. The inclusion of individual variables did not result in any change in heterogeneity between schools and the variance remained constant. There was a greater reduction of variance and MOR with the inclusion of contextual variables, with a $78.13 \%$ PCV.

The alcohol consumption among the adolescents was lower for those who studied in schools in areas with low density of alcohol outlets ( $\mathrm{OR}=0.32$; $95 \% \mathrm{CI}$ : 0.14 ; 0.73 ) when compared with those who studied in schools in areas with high density. The consumption of alcohol by mothers was associated with binge drinking among adolescents $(\mathrm{OR}=1.94$; 95\%CI: $1.14 ; 3.30)$.

Figure 2 shows how the density of alcohol outlets varies according to the proximity of each school through concentric circles with rays of 250 meters, 500 meters and $1 \mathrm{Km}$ distance from each school. The point A represents the school with the highest alcohol outlet density and the point $\mathrm{B}$ the lowest density. In the Eastern region, both public and private schools have many close points. However, in the Center-South region, there is a high concentration of alcohol outlets in comparison with others.

\section{Discussion}

The frequency of binge drinking in our study was high (39.9\%), similarly to other studies 7,9,27,31. Prevalence values varied considerably in different regions of the world. The prevalence of binge drinking in our study was obtained in the month 21,32 , which explains the difference among a previous study that revealed a prevalence of 53\% binge drinking per year among Brazilian adolescents with similar age 21 . The comparison of binge drinking among countries is complicated due to the differences in the methodology, drinking cultures, drink sizes, and other definitions as well as cultural differences 
Table 1

Distribution of the sample, bivariate analysis and crude logistic regression multilevel. Belo Horizonte, Minas Gerais State, Brazil, 2012.

\begin{tabular}{|c|c|c|c|c|c|}
\hline \multirow[t]{2}{*}{ Variables } & \multicolumn{2}{|c|}{ Total sample } & \multicolumn{2}{|c|}{ Binge drinking (\%) } & \multirow[t]{2}{*}{ Crude OR $(95 \% \mathrm{Cl})$} \\
\hline & $\mathbf{n}$ & $\%$ & No & Yes & \\
\hline \multicolumn{6}{|c|}{ Contextual factors } \\
\hline \multicolumn{6}{|c|}{ Alcohol outlet density } \\
\hline High & 80 & 18.35 & 37.50 & 62.50 & 1.00 \\
\hline Mean & 100 & 22.94 & 59.00 & 41.00 & $0.45 *(0.20 ; 1.04)$ \\
\hline Low & 256 & 58.72 & 67.58 & 32.42 & $0.34 * *(0.16 ; 0.70)$ \\
\hline \multicolumn{6}{|l|}{ Type of school } \\
\hline Public & 328 & 75.23 & 64.94 & 35.06 & 1.00 \\
\hline Private & 108 & 24.77 & 45.37 & 54.63 & $1.52 *(0.72 ; 3.21)$ \\
\hline \multicolumn{6}{|c|}{ Individual factors } \\
\hline \multicolumn{6}{|c|}{ Mother's educational level (years) } \\
\hline$\leq 7$ & 138 & 38.55 & 67.39 & 32.61 & 1.00 \\
\hline$\geq 8$ & 220 & 61.45 & 55.00 & 45.00 & 1.37 * $(0.80 ; 2.34)$ \\
\hline \multicolumn{6}{|l|}{ Sex } \\
\hline Female & 260 & 59.63 & 64.23 & 35.77 & 1.00 \\
\hline Male & 176 & 40.37 & 53.98 & 46.02 & 1.50 * $(0.99 ; 2.27)$ \\
\hline \multicolumn{6}{|l|}{ Age (years) } \\
\hline 17 & 177 & 40.60 & 58.76 & 41.24 & 1.00 \\
\hline 18 or 19 & 259 & 59.40 & 61.00 & 39.00 & $1.20 *(0.77 ; 1.88)$ \\
\hline \multicolumn{6}{|c|}{ Alcohol consumption by father } \\
\hline No & 215 & 49.31 & 72.09 & 27.91 & 1.00 \\
\hline Yes & 221 & 50.69 & 48.42 & 51.58 & $2.62 * * *(1.73 ; 3.98)$ \\
\hline \multicolumn{6}{|c|}{ Alcohol consumption by mother } \\
\hline No & 276 & 63.30 & 68.84 & 31.16 & 1.00 \\
\hline Yes & 160 & 36.70 & 45.00 & 55.00 & $2.69 * * *(1.76 ; 4.11)$ \\
\hline \multicolumn{6}{|c|}{ Alcohol consumption by siblings } \\
\hline No & 299 & 68.58 & 65.55 & 34.45 & 1.00 \\
\hline Yes & 137 & 31.42 & 48.18 & 51.82 & $2.04 * *(1.32 ; 3.15)$ \\
\hline
\end{tabular}

95\%Cl: 95\% confidence interval; OR: odds ratio.

$* \mathrm{p}<0.05$;

$* * \mathrm{p}<0.01$;

$\star * \star p<0.001$

observed 33. The high rates found for alcohol consumption among adolescents represent a significant public health concern due to the possibilities of health damage in adolescents and the possibility of a problematic consumption in adult life 4,5,6,7,34.

Our findings show positive association between mothers that consume alcohol and binge drinking among adolescents. Considered as a primary "ecological niche", in addition to the genetically transmitted inheritance, the family transmits culture, meaning and habits. The family attitude regarding the consumption of alcoholic beverages is crucial, once family can act as both risk and protective factors for the use of alcohol 20,35,36. Studies have indicated that parents that drink are less likely to establish rules against drinking for their children and have fewer discussions about alcohol at home, which can raise awareness of excessive alcohol consuption 37,38. Our results differ from the results of other studies in which best friend or siblings consumption influenced more the adolescents 27,39,40.

Binge drinking was not associated with socioeconomic condition. Some authors have shown an association between alcohol use and lower socioeconomic levels 21,41 while others point out a higher 


\section{Table 2}

Multilevel models of binge drinking and independent variables, Belo Horizonte, Minas Gerais State, Brazil, 2012.

\begin{tabular}{|c|c|c|c|}
\hline & Model 1 & Model 2 & Model 3 \\
\hline \multicolumn{4}{|c|}{ Individual factors } \\
\hline \multicolumn{4}{|c|}{ Mother's educational level (years) } \\
\hline$\leq 7$ & & 1.00 & 1.00 \\
\hline$\geq 8$ & & $1.21(0.70 ; 2.11)$ & $1.03(0.57 ; 1.86)$ \\
\hline \multicolumn{4}{|l|}{ Sex } \\
\hline Female & & 1.00 & 1.00 \\
\hline Male & & $1.44(0.88 ; 2.36)$ & $1.52(0.93 ; 2.49)$ \\
\hline \multicolumn{4}{|l|}{ Age (years) } \\
\hline 17 & & 1.00 & 1.00 \\
\hline 18 or 19 & & $1.00(0.60 ; 1.66)$ & $0.97(0.59 ; 1.60)$ \\
\hline \multicolumn{4}{|c|}{ Alcohol consumption by father } \\
\hline No & & 1.00 & 1.00 \\
\hline Yes & & $1.63(0.95 ; 2.79)$ & $1.57(0.92 ; 2.68)$ \\
\hline \multicolumn{4}{|c|}{ Alcohol consumption by mother } \\
\hline No & & 1.00 & 1.00 \\
\hline Yes & & $1.93 *(1.13 ; 3.29)$ & $1.94 *(1.14 ; 3.30)$ \\
\hline \multicolumn{4}{|c|}{ Alcohol consumption by siblings } \\
\hline No & & 1.00 & 1.00 \\
\hline Yes & & $1.55(0.92 ; 2.62)$ & $1.55(0.92 ; 2.61)$ \\
\hline \multicolumn{4}{|c|}{ Contextual factors } \\
\hline \multicolumn{4}{|c|}{ Alcohol outlet densities } \\
\hline High & & & 1.00 \\
\hline Mean & & & $0.60(0.22 ; 1.67)$ \\
\hline Low & & & $0.32 * *(0.14 ; 0.73)$ \\
\hline \multicolumn{4}{|l|}{ Type of school } \\
\hline Public & & & 1.00 \\
\hline Private & & & $1.24(0.58 ; 2.68)$ \\
\hline MOR & 1.71 & 1.75 & 1.28 \\
\hline Var (schools) & $0.32(0.10 ; 0.88)$ & $0.32(0.10 ; 1.17)$ & $0.07(0.01 ; 2.29)$ \\
\hline PCV & - & $0.00 \%$ & $78.13 \%$ \\
\hline
\end{tabular}

MOR: median odds ratio; PCV: proportional change in variance; Var: variance.

Note: exponentiated coefficients; 95\% confidence intervals in parenthesis. Interaction between alcohol consumption by father and mother's educational level with alcohol consumption by mother were not significant.

* $\mathrm{p}<0.05$;

$\star * p<0.01$.

prevalence when the socioeconomic level is higher 42,43 . There was no significant association between the binge drinking and mother's level of education, which agrees with other studies 27,44 . The evaluation of the influence of maternal schooling on binge drinking in developing countries is more complex, since more years of schooling result minimally in increased income 44 .

In our study, no statistically significant association was found between binge drinking and sex. Women have been redefining their gender identities, and the increased alcohol consumption may change social positions 39 . Behaviors historically considered exclusive to men such as going out to bars are currently being observed among women, especially among the younger ones 45 . Women have not been as heavily stigmatized in recent decades for consuming alcoholic beverages as in the past 46 . These changes may have contributed to our findings regarding the association among consumption and sex. 


\section{Figure 2}

Alcohol outlets according to the proximity of each school with emphasis on the areas of greatest and lowest density. Belo Horizonte, Minas Gerais State, Brazil 2012.

2a) Alcohol outlets
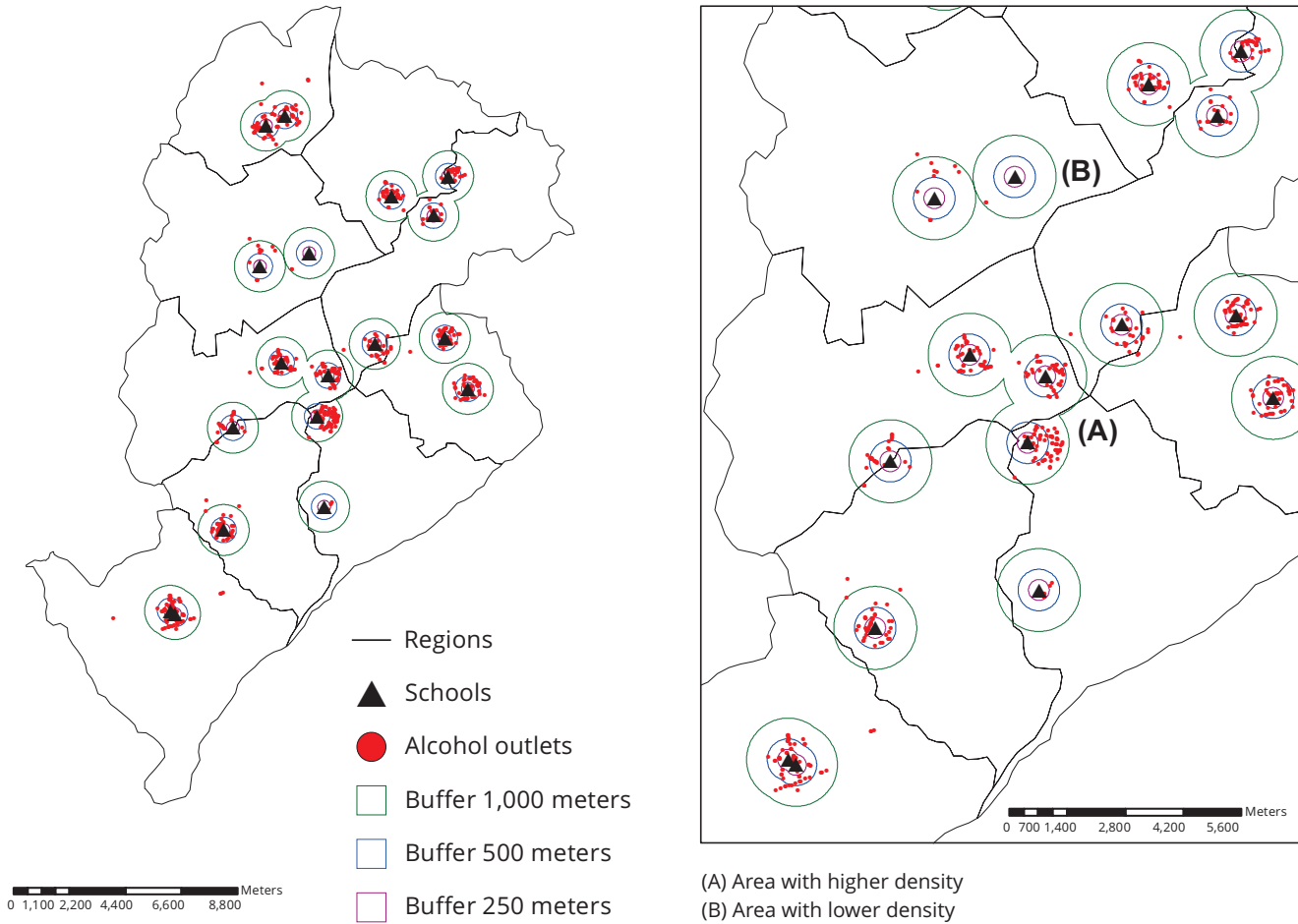

(A) Area with higher density (B) Area with lower density

2b) Density
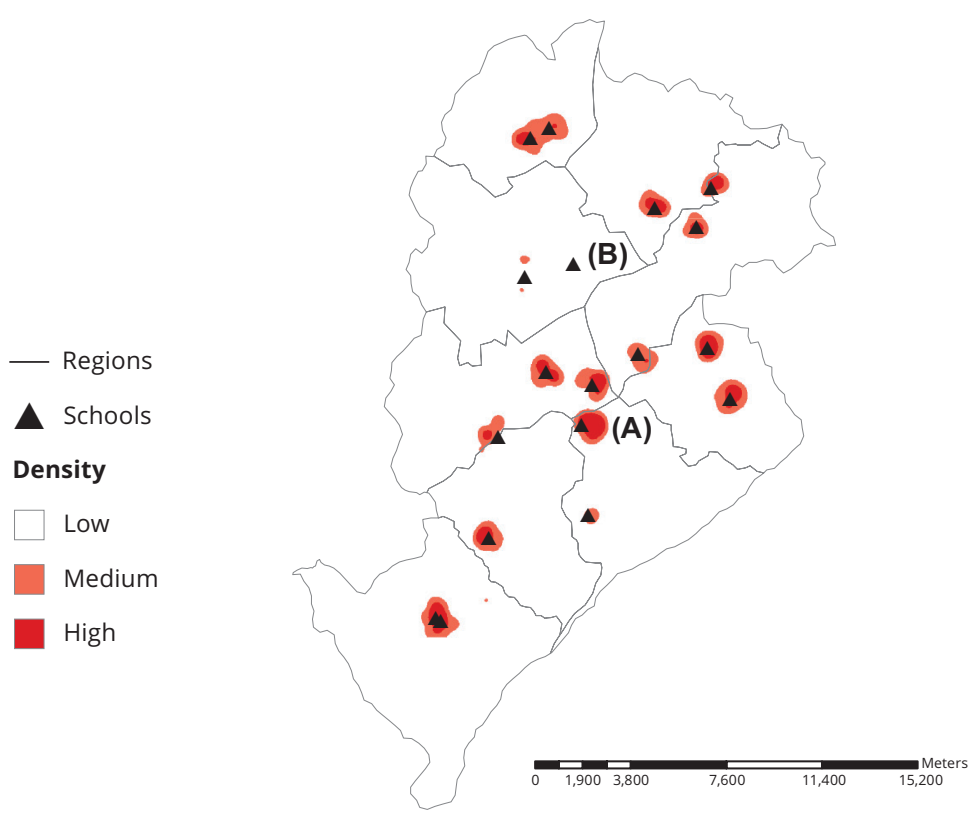
The high alcohol outlet density around schools was found to be significantly associated with binge drinking among adolescents. In the final model, the individual and contextual variables associated were considered and the effect of the contextual variable was significant. This is an evidence that the numbers of alcohol outlets is a critical component in alcohol consumption. Proximity and density are both important in defining physical availability of alcohol 14,16, corroborating previous studies $47,48,49$. The social cognitive theory supports that environment stimulate or strengthen alcohol use behavior 50 .

We emphasize that as the number of outlets increases, outlet sellers experience more competition and, thus, greater pressure to be lenient as one way to guarantee the sales 51 , which can be linked to the purchase of alcohol by adolescents. Restrict the number of outlets, increase the distance from schools and more supervision of law enforcement may reduce alcohol consumption among adolescents 49,51.

Brazil doesn't have a law that delimits a minimum distance of alcohol outlets from schools. A law project was created establishing a minimum distance of three kilometers of alcohol outlets from public and private schools and universities; however, it has not been approved 52 . Greater density could result in greater exposure to environmental factors such as advertisements, encouraging alcohol consumption 51. On the other hand, no study was found in Brazil associating alcohol outlet density around schools with binge drinking in an adolescent population. Despite its cross-sectional design, our study points the need of laws and gives scientific support for an even smaller distance between schools and alcohol outlets than established by the aforementioned law project.

The multilevel model investigates how the environment, individual-level factors and their interactions can influence health. This complex statistical method has been used since it allows the researchers to structure and organize predictive models that can explain the effect of different variables on individual behavior. The environment is a key factor in public health, thus, it has to be analyzed 53,54,55 to develop and adopt the most preventive measures regarding alcohol consumption among adolescents.

Despite these findings, we think it is important to observe that other sources can facilitate the consumption of alcoholic beverages among adolescents. A study with a representative sample of Brazilian adolescents showed that most of the adolescents reported drinking alcohol frequently with friends, parents in places such as their household, friend's houses, clubs, parks, restaurants, public spaces, sporting events, newsagent's shop, cars and even in the school 56. The fear of stigma may prevent them from drinking in certain places such as school vicinity 16 . A joint effort must be established to reduce binge drinking among adolescents.

Our study has some limitations. First, this is a cross-sectional study, and, although its associations may provide important clues, they are not necessarily causal. Second, the sample is not representative, therefore, the results can't be generalized. Third, alcohol consumption was self-reported rather than objectively measured, however, the self-reported quantity-frequency measure based on the previous month of drinking exhibits good reliability 22,57 . Fourth, despite the innovation of our study in evaluating alcohol outlet density, some confused factors were not measured.

This study contributes to the body of literature by emphasizing studies that impact the environment on most adolescents living in Belo Horizonte, and by contextualizing the association between individual and contextual factors with student binge drinking in their relevant school-attachments.

Planning and public policy implementation requires additional studies identifying more environmental features that can affect adolescent health outcomes and what distances are considered meaningful exposures for adolescents in Brazil. Moreover, studies on the effect of exposure to outlets on the normative beliefs of adolescents are also needed to determine if exposure may influence adolescent's perceptions of the normative nature of alcohol use. Finally, another important step is replicating our study based on the adolescent's household location, where social interactions (including family members) are more evident.

Longitudinal study analysis would help to clarify the most important conceptualizations of performance improvement, along with the interaction among the potential mechanisms.

The conclusions of our study showed that binge drinking among adolescents was associated with density of alcohol outlets around the schools and with mother's alcohol consumption. 


\section{Contributors}

J. G. Martins and K. O. Jorge contributed to the data analysis and interpretation; article writing and critical review of intellectual content; final approval of the version to be published; responsible for all aspects of the article in ensuring the accuracy and integrity of any part of the article. M. O. Guimarães contributed to the article writing, critical review of intellectual content and final approval of the version to be published. C. J. P. Silva contributed to the data interpretation; creation of maps; critical review and final approval of the version to be published; responsible for all aspects of the article in ensuring the accuracy and integrity of any part of the article. R. C. Ferreira contributed to the data analysis and interpretation; critical review of intellectual content; final approval of the version to be published; responsible for all aspects of the article in ensuring the accuracy and integrity of any part of the article. I. A. Pordeus contributed with the critical review of intellectual content; final approval of the version to be published; responsible for all aspects of the work in ensuring the accuracy and integrity of any part of the article. I. Kawachi and P. M. P. A. Zarzar contributed to the study design; data analysis and interpretation; article writing and critical review of intellectual content; final approval of the version to be published; responsible for all aspects of the article in ensuring the accuracy and integrity of any part of the article.

\section{Additional informations}

ORCID: Juliana Gabrielle Martins (0000-00034960-0173); Mariana Oliveira Guimarães (00000001-6563-0079); Kelly Oliva Jorge (0000-00016829-6029); Carlos José de Paula Silva (00000001-5188-4625); Raquel Conceição Ferreira (0000-0001-8897-9345); Isabela Almeida Pordeus (0000-0002-5902-7481); Ichiro Kawachi (00000003-3579-4456); Patrícia Maria Pereira de Araújo Zarzar (0000-0002-6952-5767).

\section{Acknowledgments}

This study was financed in part by the Brazilian Graduate Studies Coordenating Board (Capes; Finance Code 001, and supported by the Brazilian National Research Council (CNPq).

\section{References}

1. Gore FM, Bloem PJ, Patton GC, Ferguson J, Joseph V, Coffey C, et al. Global burden of disease in young people aged 10-24 years: a systematic analysis. Lancet 2011; 377:2093-102.

2. Brasil. Lei no 9.294, de 15 de julho de 1996. Dispõe sobre as restrições ao uso e à propaganda de produtos fumígeros, bebidas alcoólicas, medicamentos, terapias e defensivos agrícolas, nos termos do $\$$ 4o do art. 220 da Constituição Federal. Diário Oficial da União 1996; 16 jul.

3. Carlini ELA, Noto AR, Sanchez ZV, Carlini CMA, Locatelli DP, Abeid LR, et al. VI levantamento nacional sobre o consumo de drogas psicotrópicas entre estudantes do ensino fundamental e médio das redes pública e privada de ensino nas 27 capitais brasileiras - 2010 . São Paulo: Centro Brasileiro de Informações sobre Drogas Psicotrópicas, Universidade Federal de São Paulo/Brasília: Secretaria Nacional de Políticas sobre Drogas; 2012.

4. Walsh K, Moreland AM, Hanson RF, Resnick HS, Saunders BE, Kilpatrick DG. Relationship violence victimization and binge drinking trajectories among a nationally representative sample of adolescents. J Adolesc 2017; 58:4955.

5. Wang H, Hu R, Zhong J, Du H, Fiona B, Wang $\mathrm{M}$, et al. Binge drinking and associated factors among school students: a cross-sectional study in Zhejiang Province, China. BMJ Open 2018; 8:e021077.

6. Hingson RW, Zha W. Binge drinking above and below twice the adolescent thresholds and health-risk behaviors. Alcohol Clin Exp Res 2018; 42:904-13.

7. Raposo JCDS, Costa ACQ, Valença PAM, Zarzar PM, Diniz ADS, Colares V, et al. Binge drinking and illicit drug use among adolescent students. Rev Saúde Pública 2017; 51:83.

8. Kuntsche E, Ravens-Sieberer U. Monitoring adolescent health behaviours and social determinants cross-nationally over more than a decade: introducing the Health Behaviour in School-aged Children (HBSC) study supplement on trends. Eur J Public Health 2015; 25 Suppl 2:1-3.

9. Martins JG, de Paiva HN, Paiva PCP, Ferreira RC, Pordeus IA, Zarzar PM, et al. New evidence about the "dark side" of social cohesion in promoting binge drinking among adolescents. PLoS One 2017; 12:e0178652.

10. Doumas DM, Miller R, Esp S. Impulsive sensation seeking, binge drinking, and alcoholrelated consequences: do protective behavioral strategies help high risk adolescents? Addict Behav 2017; 64:6-12.

11. Link BG, Phelan J. Social conditions as fundamental causes of disease. J Health Soc Behav 1995; Spec No:80-94.

12. Kumar R, O'Malley PM, Johnston LD, Schulenberg JE, Bachman JG. Effects of school-level norms on student substance use. Prev Sci 2002; 3:105-24. 
13. Gruenewald PJ, Johnson FW. The stability and reliability of self-reported drinking measures. J Stud Alcohol 2006; 67:738-45.

14. Weitzman ER, Folkman A, Folkman MP, Wechsler H. The relationship of alcohol outlet density to heavy and frequent drinking and drinking-related problems among college students at eight universities. Health Place 2003; 9:1-6.

15. Toomey TL, Lenk KM, Wagenaar AC. Environmental policies to reduce college drinking: an update of research findings. J Stud Alcohol Drugs 2007; 68:208-19.

16. Young R, Macdonald L, Ellaway A. Associations between proximity and density of local alcohol outlets and alcohol use among Scottish adolescents. Health Place 2013; 19:124-30.

17. Scribner RA, Cohen DA, Fisher W. Evidence of a structural effect for alcohol outlet density: a multilevel analysis. Alcohol Clin Exp Res 2000; 24:188-95.

18. Prefeitura de Belo Horizonte. Planos diretores regionais. https://prefeitura.pbh.gov.br/index. $\mathrm{php} /$ politica-urbana/planejamento-urbano// plano-diretor/regionais (acessado em 06/Jun/ 2019).

19. Martins-Oliveira JG, Jorge KO, Ferreira RC, Ferreira EFE, Vale MP, Zarzar PM. Risk of alcohol dependence: prevalence, related problems and socioeconomic factors. Ciênc Saúde Colet 2016; 21:17-26.

20. Jorge KO, Ferreira RC, Ferreira EF, Vale MP, Kawachi I, Zarzar PM. Binge drinking and associated factors among adolescents in a city in southeastern Brazil: a longitudinal study. Cad Saúde Pública 2017; 33:e00183115.

21. Pinsky I, Sanches M, Zaleski M, Laranjeira R, Caetano R. Patterns of alcohol use among Brazilian adolescents. Rev Bras Psiquiatr 2010; 32:242-9.

22. Meneses-Gaya C, Zuardi AW, Loureiro SR, Hallak JE, Trzesniak C, de Azevedo Marques $\mathrm{JM}$, et al. Is the full version of the AUDIT really necessary? Study of the validity and internal construct of its abbreviated versions. Alcohol Clin Exp Res 2010; 34:1417-24.

23. de Paiva HN, Paiva PC, de Paula Silva CJ, Lamounier JA, Ferreira e Ferreira E, Ferreira RC, et al. Is there an association between traumatic dental injury and social capital, binge drinking and socioeconomic indicators among schoolchildren? PLoS One 2015; 10:e0118484.

24. Kavanagh AM, Kelly MT, Krnjacki L, Thornton L, Jolley D, Subramanian SV, et al. Access to alcohol outlets and harmful alcohol consumption: a multilevel study in Melbourne, Australia. Addiction 2011; 10:1772-9.

25. Halonen JI, Kivimäki M, Virtanen M, Pentti J, Subramanian SV, Kawachi I, et al. Proximity of off-premise alcohol outlets and heavy alcohol consumption: a cohort study. Drug Alcohol Depend 2013; 132:295-300.

26. Alves MTG, Soares JF. Medidas de nível socioeconômico em pesquisas sociais: uma aplicação aos dados de uma pesquisa educacional. Opin Pública 2009; 15:1-30.
27. Zarzar PM, Jorge KO, Oksanen T, Vale MP, Ferreira EF, Kawachi I. Association between binge drinking, type of friends and gender: a cross-sectional study among Brazilian adolescents. BMC Public Health 2012; 12:257.

28. Instituto Brasileiro de Geografia e Estatística. Pesquisa Nacional por Amostra de Domicílios. Rio de Janeiro: Instituto Brasileiro de Geografia e Estatística; 2012.

29. Austin PC, Stryhn H, Leckie G, Merlo J. Measures of clustering and heterogeneity in multilevel Poisson regression analyses of rates/ count data. Stat Med 2018; 37:572-89.

30. Merlo J, Chaix B, Ohlsson H, Beckamn A, Johnell K, Hjerpe P, et al. A brief conceptual tutorial on multilevel analysis in social epidemiology: investigating contextual phenomena in different groups of people. J Epidemiol Community Health 2006; 59:729-36.

31. Gomes K, Amato TC, Bedendo A, Santos ELD, Noto AR. Problems associated with binge drinking among students in Brazil's state capitals. Ciênc Saúde Colet 2019; 24:497-507.

32. Alarcón AM, Muñoz NS, Grandjean BM. Alcohol consumption among high school students from the Araucanía-Chile: ethnicity and residence. Rev Chil Pediatr 2018; 89:454-61.

33. Piano MR, Mazzuco A, Kang M, Phillipis SA. Binge drinking episodes in young adults: how should we measure them in a research setting? J Stud Alcohol Drugs 2017; 78:502-11.

34. Hingson R, Zha W, Smyth D. Magnitude and trends in heavy episodic drinking, alcohol-impaired driving, and alcohol-related mortality and overdose hospitalizations among emerging adults of college ages 18-24 in the United States, 1998-2014. J Stud Alcohol Drugs 2017; 78:540-8.

35. Abar C, Abar B, Turrisi R. The impact of parental modeling and permissibility on alcohol use and experienced negative drinking consequences in college. Addict Behav 2009; 34:542-7.

36. Fairlie AM, Wood MD, Laird RD. Prospective protective effect of parents on peer influences and college alcohol involvement. Psychol Addict Behav 2012; 26:30-41.

37. Wood MD, Read JP, Palfai T, Stevenson J. Social influence processes and college student drinking: the mediational role of alcohol outcome expectancies. J Stud Alcohol 2001; 62:32-43.

38. Crawford LA, Novak KB. Parental and peer influences on adolescent drinking: the relative impact of attachment and opportunity. J Child Adolesc Subst Abuse 2002; 12:1-26.

39. Guimarães MO, Paiva PCP, Paiva HN, Lamounier JA, Ferreira EFE, Zarzar PMPA. Religiosity as a possible protective factor against "binge drinking" among 12-year-old students: a population-based study. Ciênc Saúde Colet 2018; 23:1067-76.

40. Chartier KG, Hesselbrock MN, Hesselbrock VM. Development and vulnerability factors in adolescent alcohol use. Child Adolesc Psychiatr Clin N Am 2010; 19:493-504. 
41. Mendoza-Sassi RA, Béria JU. Prevalence of alcohol use disorders and associated factors: a population-based study using AUDIT in southern Brazil. Addiction 2003; 98:799-804.

42. Almeida-Filho N, Lessa I, Magalhães L, Araújo M, Aquino E, Kawachi I, et al. Alcohol drinking patterns by gender, ethnicity, and social class in Bahia, Brazil. Rev Saúde Pública 2004; 38:45-54

43. Humensky JL. Are adolescents with high socioeconomic status more likely to engage in alcohol and illicit drug use in early adulthood? Subst Abuse Treat Prev Policy 2010; 5:19.

44. Ferreira LN, Sales ZN, Casotti CA, Bispo Júnior JP, Braga Júnior ACR. Perfil do consumo de bebidas alcoólicas e fatores associados em um município do Nordeste do Brasil. Cad Saúde Pública 2011; 27:1473-86.

45. Rossow I, Kuntsche E. Early onset of drinking and risk of heavy drinking in young adulthood - a 13-year prospective study. Alcohol Clin Exp Res 2013; 37 Suppl 1:E297-304.

46. Wolle CC, Sanches M, Zilberman ML, Caetano R, Zaleski M, Laranjeira RR, et al. Differences in drinking patterns between men and women in Brazil. Rev Bras Psiquiatr 2011; 33:367-73.

47. Huckle T, Huakau J, Sweetsur P, Huisman O, Casswell S. Density of alcohol outlets and teenage drinking: living in an alcogenic environment is associated with higher consumption in a metropolitan setting. Addiction 2008; 103:1614-21.

48. Chen MJ, Remer LG. Does alcohol outlet density affect youth access to alcohol? J Adolesc Health 2009; 44:582-9.

49. Rowland B, Toumbourou JW, Livingston M. The association of alcohol outet density with illegal underage adolescent purchasing of alcohol. J Adolesc Health 2015; 56:146-52.

50. Baronanowski T, Perry CI, Parcel GS. How individuals, environments, and health behavior interact: social cognitive theory. In: Glanz $\mathrm{K}$, Rimer BK, Viswanath $\mathrm{K}$, editors. Health behavior and health education: theory, research, and practice. San Francisco: Jossey-Bass; 2008. p. 165-84.
51. Campbell CA, Hahn RA, Elder R, Brewer R, Chattopadhayay S, Fielding J, et al. The effectiveness of limiting alcohol outlet density as a means of reducing excessive alcohol consumption and alcohol-related harms. Am J Prev Med 2009; 37:556-69.

52. Câmara dos Deputados. PL 1.052/2015. Dispõe sobre a restrição da venda de bebidas alcoólicas a uma distância mínima de 3 quilômetros de estabelecimentos, públicos e privados, de ensino fundamental, médio e superior. https://www.camara.leg.br/proposicoesWeb/ fichadetramitacao?idProposicao $=1198830$ (acessado em 06/Jun/2019).

53. Mori-Gamarra F, Moure-Rodríguez L, Sureda X, Carbia C, Royé D, Montes-Martínez A, et al. Alcohol outlet density and alcohol consumption in Galician youth. Gac Sanit 2018; [Epub ahead of print].

54. Puente-Palacios KE, Laros JA. Análise multinível: contribuições para estudos sobre efeito do contexto social no comportamento individual. Estud Psicol (Campinas) 2009; 26:349-61.

55. Diez-Roux AV. Multilevel analysis in public health research. Annu Rev Public Health 2000; 21:171-92

56. Vieira DL, Ribeiro M, Romano M, Laranjeira RR. Alcohol and adolescents: study to implement municipal policies. Rev Saúde Pública 2007; 41:396-403.

57. Gruenewald PJ, Johnson FW. The stability and reliability of self-reported drinking measures. J Stud Alcohol 2006; 67:738-45. 


\section{Resumo}

O estudo teve como objetivo avaliar a prevalência de consumo excessivo episódico de álcool entre adolescentes e a associação com a densidade de locais de venda de bebidas alcoólicas no entorno das escolas. Um estudo transversal foi realizado em Belo Horizonte, Minas Gerais, Brasil, com 436 estudantes de segundo grau entre 17 e 19 anos de idade matriculados em 18 escolas públicas e privadas. Os estudantes responderam perguntas do Alcohol Use Disorder Identification Test (AUDIT-C) sobre consumo de álcool pelos pais e irmãos, além de características socioeconômicas (tipo de escola, escolaridade materna). Foram utilizados dados de sistemas de informações geográficas para calcular a densidade de locais de venda de bebidas alcoólicas em torno das escolas participantes. A associação entre variáveis independentes e consumo excessivo episódico de álcool foi investigada por análise de regressão logística multivariada ( $p<$ $0,05)$ com interceptos randômicos e inclinações fixas. Foi adotada uma estratégia de modelagem sequencial em três passos. A prevalência de consumo excessivo episódico de álcool foi de 39,9\%. O consumo de álcool entre adolescentes foi mais baixo naqueles que estudavam em áreas com baixa densidade de locais de venda de bebidas alcoólicas em torno das escolas (OR =0,32; IC95\%: 0,14; 0,73), e o consumo de álcool pelas mães esteve associado ao consumo excessivo episódico de álcool pelos adolescentes $(O R=1,94$; IC95\%: 1,14; 3,30), Em conclusão, consumo excessivo episódico de álcool por adolescentes mostrou associação com a densidade de locais de venda de bebidas alcoólicas no entorno das escolas e com o consumo materno de álcool.

Consumo de Bebidas Alcoólicas; Bebedeira; Adolescente

\section{Resumen}

El objetivo de este estudio fue evaluar la prevalencia del consumo compulsivo de alcohol por parte de adolescentes y su asociación con la densidad de establecimientos de venta de alcohol próximos a escuelas. Este estudio transversal se realizó en Belo Horizonte, Minas Gerais, Brasil, con 436 estudiantes de escuelas secundarias con edades comprendidas entre los 17-19 años, inscritos en 18 escuelas públicas y privadas. Los estudiantes completaron con Alcohol Use Disorder Identification Test (AUDIT-C) preguntas sobre el consumo de alcohol por parte de padres y hermanos, así como de su estatus socioeconómico (tipo de escuela, nivel de escolarización de la madre). Los datos del sistema de informaciones geográficas se usaron para calcular la densidad de establecimientos de venta de alcohol en los alrededores de las escuelas participantes. La asociación entre las variables exploratorias y el consumo compulsivo de alcohol fue investigado usando un análisis de regresión logística multinivel $(p<0,05)$ con intersecciones aleatorias y curvas fijas. Se adoptó una estrategia de modelado secuencial en tres pasos. La prevalencia de consumo compulsivo de alcohol fue de 39,9\%. El consumo de alcohol entre adolescentes fue más bajo entre quienes estudiaban en áreas con baja densidad de establecimientos de venta de alcohol alrededor de las escuelas (OR =0,32; IC95\%: 0,14; 0,73), además el consumo de alcohol en madres estuvo asociado con el consumo de alcohol en adolescentes $(O R=1,94$; IC95\%: 1,14; 3,30). La conclusión fue que el consumo compulsivo de alcohol en adolescentes estaba asociado con la densidad de establecimientos de venta de alcohol en los alrededores de las escuelas y el consumo de alcohol por parte de la madre.

Consumo de Bebidas Alcohólicas; Borrachera; Adolescente
Submitted on 18/Mar/2019

Final version resubmitted on 29/Jun/2019

Approved on 09/Jul/2019 